\title{
Comprehensive Internationalisation in Latin America
}

Jocelyne Gacel-Ávila

University of Guadalajara, Guadalajara, López Cotilla \#1043, Mexico.

E-mail: jocelyne@cgci.udg.mx

The Latin American tertiary education (TE) sector is nowadays facing demands from globalisation and a knowledge-based society, while still dealing with challenges in terms of access, equity, quality and relevance. This new context has prompted a greater demand for TE and is forcing institutions to reconsider their mission, tasks and responsibilities, as well as to develop innovative approaches to improve their relevance and function, among which comprehensive internationalisation is considered a key strategy. The aim of the present article is therefore to assess the status of the internationalisation process of the Latin American TE sector through a piecemeal analysis of empirical findings and data coming from the most recently published research and studies on rationales, benefits, obstacles, policies, strategies and programmes. The findings will be put in perspective with international trends and progress achieved in different regions, thus making it possible to draw some conclusions for our region. As background information, the main achievements and challenges of the Latin American sector will be depicted.

Higher Education Policy (2012) 25, 493-510. doi:10.1057/hep.2012.9;

published online 12 June 2012

Keywords: internationalisation; Latin America; higher education; tertiary education

\section{Introduction}

The Latin American tertiary education (TE) sector is nowadays facing the challenge to meet the demands from globalisation and a knowledge-based society, while still dealing with insufficient access, quality, relevance and equity. In all countries, this new context has prompted a greater demand for education, and is forcing institutions of higher learning to reconsider their mission, tasks and responsibilities, as well as to develop innovative strategies to improve their relevance and function, among which internationalisation is considered one of the key components to meeting emerging challenges. Therefore, it is important for the region to assess the status of its internationalisation process, rationales, benefits, obstacles, policies, strategies and programmes. The methodology used follows the OECD Guidelines for Quality Assessment in Internationalisation (Knight and De Wit, 1999), which 
are accepted worldwide and apply to developed and developing countries and regions. On the basis of common concepts and topics, this review allows comparability with international trends and progress made in different regions, thus making it possible to draw some conclusions for our region. The present article will also depict the main characteristics, present achievements and challenges of the Latin American TE sector as background information to understand regional context and its impact on the internationalisation process.

\section{A Comprehensive Internationalisation Concept}

The 21 st century society is characterised by a rapidly changing, competitive, multicultural and global context. Economic growth and social progress are increasingly dependent on the production, distribution and application of knowledge, the availability of a competitive skilled human capital, as well as a high added value service sector like education, information and so on. The Implications for TE are huge, as nations need new policies and approaches to strengthen their capacity to negotiate and improve their participation in the world context. Competitiveness in the knowledge society implies a better quality of education: '.. the economic and geopolitical race of the 21 st century is a competition between educational systems ...' (Gómez Buendía, 1998, 17). To be relevant, today's education must develop in students skills such as flexibility, creativity, autonomy, innovation, capacity to respond rapidly to change, adaptation and cooperative work. In addition, education must conceptualise everything in accordance within the age of globalisation and the environment and complexity of the planet. Knowledge of the world itself has become a vital intellectual necessity, just as the solution to international problems requires a global approach and planning process. Educational strategies in the 21 st century must be built on a common foundation, and which include the search for a standard of competitive teaching on an international level, but adapted to local conditions. One of TE's basic and fundamental functions should be the fostering of a global consciousness among students, to make them understand the relation of interdependence between peoples and societies, to appreciate their own and other cultures and have respect for pluralism and diversity. All these aspects are the foundations of solidarity and peaceful coexistence among nations and of a true global citizenship. Internationalisation strategies constitute an important tool in bringing to fruition a new educational vision, and should be focused on an updating of academic content, making global phenomena understandable while promoting intercultural understanding and sustainable human development. Internationalisation is one of the educational strategies with the potential to enhance the cognitive skills demanded by the new context. Indeed, 
when students leave their own cultural environment - for study abroad or academic programmes based on intercultural communication techniques with contents that highlight the international and global dimension of human and social interaction - they have the possibility, for instance, to develop a capacity for adaptation, flexibility, autonomy, to broaden their cultural and intellectual horizons, to increase their levels of intercultural tolerance and interpersonal communication through experiencing different idiosyncrasies (Mestenhauser, 1998).

Nevertheless, in order to achieve the scope of the above-mentioned objectives, the process of internationalisation must be implemented in the TE sector through a comprehensive internationalisation concept (Knight and De Wit, 1995), meaning in a systematic and holistic way, going beyond the traditional notion of international cooperation and physical mobility of individuals. The notion of comprehensiveness means that strategies should be transversal to the whole policy design, integrating the international dimension in all institutional policies and programmes, and impact the three levels of the educational process: macro (decision making and design of institutional policies), medium (curriculum structure and policy) and micro (teaching and learning process). Internationalisation policies must be comprehensive and transversal in order to help improve the quality and relevance of TE, as well as to support the necessary changes in the educational system that will enable it to adapt to the new global reality. Furthermore, it is important to understand the different scale of internationalisation strategies: the ones affecting individuals, such as mobility; and the ones impacting the system itself, like the internationalisation of the curriculum and research. According to Change Theory (Fullan, 2006), systemic strategies are the ones with the capacity to provoke change and transformation in the system. This is the reason why, the concept of comprehensive internationalisation must be enforced in Latin America (LA) in order to have the potential to trigger the transformations required by the whole system to adapt to the new demands of society. The present article will assess to what extent the internationalisation process in LA follows this concept.

\section{A Brief Description of TE Systems in LA}

During the last decades of the 20th century, the Latin American TE sector saw a period of expansion and a first set of reforms was implemented to overcome deficits in access, quality, relevance and equity. In the seventies, TE massification took place, and today's enrolment is approximately 18 million students, with an average access rate of $38 \%$, which is still insufficient compared with the $70 \%$ of North America and Western Europe or the $64 \%$ of 
Central and Eastern Europe. In Argentina, Mexico and Venezuela, most of the expansion took place owing to the public sector; while for Brazil, Colombia, Chile and Peru, it was achieved through increased participation of the private sector, which nowadays represents $44.2 \%$ of the region's enrolment. Nevertheless, equity is still a pending challenge, as for every 27 graduates from Quintile 5 at undergraduate level, there is one from Quintile 1 (CEPAL, 2010).

Differentiation has been an outcome of expansion, having nowadays a wider typology of TEls like traditional, technological, macro-universities, research centres, professional and vocational schools, technological institutes, from both public and private sectors. Differentiation in types of programmes has been uneven: while in some countries, enrolment is mostly at $5 \mathrm{~A}$ professional and disciplinary programmes (96\% in Mexico and 90\% in Brazil); some others have developed a larger 5B occupational oriented sector, like Chile (49\%), Colombia (31\%) and Argentina (31\%), which is similar to countries like France, the United States and South Korea.

In the nineties, much greater concern on quality and relevance was shown, especially in light of the sector deterioration caused by recurrent and profound economic crises, budget reduction and political tensions, as a result of the damage caused by the previous so-called 'lost decade'. A series of policies and programmes for change was articulated around two main objectives: first, to overcome negative outcomes in terms of quality; and second, to modernise the sector applying recommendations from international organisations. ${ }^{1}$ These reforms mainly intend to set up quality assurance systems, and new rules for public funding.

The major enrolment is in social sciences, economics, business and law, amounting to $50 \%$ in Colombia and $42 \%$ in Mexico, in contrast with $20 \%$ in a newly industrialised country like South Korea and $30 \%$ in an advanced economy like the United Kingdom (UNESCO, 2010). This implies the saturation of these areas in terms of employment, and an internationally divergent trend in respect to academic offer and graduates' profile.

Another relevant topic for quality and relevance in the region is the reform of the prevalent traditional educational model, in particular for the search of international accreditation and participation in world trends such as regional academic integration. The first cycle of studies is a licenciatura, whose main function is to provide a 'licence' for the practice of a profession. The professional curriculum is usually rigid and highly specialised with a 4 or 5-year heavy course load, including a lengthy dissertation as a graduation requisite. As a result, graduation rates are low, ranging from $11 \%$ to $21 \%$ in Argentina, Brazil, Chile and Mexico. Correspondence teaching is also usually very traditional, focused on expository methods and note-taking, making little emphasis on the development of reasoning, problem-solving abilities and transversal competencies. This model does not respond to 21 st century education guidelines, which are student-centred and focused on the development 
of sophisticated cognitive skills, learning autonomy throughout life, and 'learn to learn' skills, giving more weight to general education.

Another negative impact on TE is the low quality of the previous levels of education (basic and secondary education), as shown by LA low ranking in the Programme for International Student Assessment. While the OECD average is of 501 for science, 496 for mathematics and 493 reading, the region's performance in that test is the lowest, ranging between the highest score of Chile with 447, 421 and 449, and the lowest of Peru with 369, 365 and 370, respectively (OECD, 2010b).

$\mathrm{TE}$ is still in a slow, ongoing process of acquiring full-time and tenured faculty who have undergone postgraduate study. As the educative model is predominantly oriented towards traditional professions, there is a majority of part-time faculty coming from professional fields, and who hold no postgraduate degree and are not involved in research. Presently, 70\% of the faculty hold a Bachelor's degree (licenciatura), 26\% a Master's and only 4\% a Ph.D., and have no full-time appointment $(60 \%$ in the public and $86 \%$ in the private sector) (De Wit et al., 2005).

In respect to research capacity, postgraduate programmes were established relatively late - in the eighties and nineties - and represent nowadays an enrolment rate of $4.2 \%$, with a majority at Master's level. Doctoral programmes show a low 1\% enrolment rate in Argentina, Brazil and Mexico (compared with $7 \%$ in Finland), and are insufficient in some areas, especially in scientific fields. By 2008, Argentina reached a number of 979.5 researchers per 1 million inhabitants; Brazil 656.9 and Mexico 352.9, compared with 4,627.2 in South Korea. As a result, there is insufficient critical mass for the consolidation of research and knowledge production. In addition, most of the researchers are concentrated in TE institutions (TEIs) (Chile 73.7\%, Brazil 64.7\%, Argentina $49.3 \%$, Mexico 47\%), in contrast with $17.5 \%$ in countries like South Korea. Consequently, research is mainly carried out for academic purposes, and therefore has a minor impact on the production process and competitiveness. Knowledge transfer is usually scarce, and the productive sector is not actively supporting R\&D, which results in a low capacity for innovation.

The capacity to respond to contemporary demands can be estimated through different international rankings, which are, if not infallible, still useful as references to measure trends in a specific area and region. Such is the case of the 2011-2012 Global Competitiveness Index, where Chile ranks 31st, Brazil 53rd, Mexico 58th, Colombia 68th and Argentina 85th. As for the Economy of Knowledge Index, Latin American countries got an average score of 5.21 out of 10, with the exception of 7.09 for Chile. Notwithstanding differences in context, these figures show trends and gaps that LA needs to reverse. To the extent that education contributes to human development and competitiveness, these indicators highlight the need for a reform in the educational system. 
To sum up, students' learning outcomes and competitiveness have been hampered by an obsolete educational model, an outdated academic offer and insufficient professionalisation of faculty; furthermore, knowledge production has been limited by an insufficient critical mass of qualified scholars and scarce investment in science and technology. Indicators point that TE needs more than accreditation and quality assurance processes per se to overcome the present situation, and makes it difficult to meet the demands of a knowledgebased society, which needs high quality TE systems, internationally competitive graduates and increased knowledge production. The TE sector needs to improve at a faster pace, in order to reduce gaps, not only with developed countries, but also with emergent countries. Unfortunately, the sector is suffering both from a lack of long-standing public policies and financial resources. A more proactive approach to TE and research is needed through the establishment of long-term strategies to shape the agenda for the future rather than reacting to changes introduced by international stakeholders. All these aspects negatively impact the region's internationalisation process, whose consolidation needs long-term state policies, substantial reforms in curriculum and research, a professionalised and international profile faculty, as well as an updated academic offer and infrastructure, amongst others.

\section{A Review of Internationalisation Strategies in LA}

The topic of internationalisation was generally absent in TE studies and research 15 years ago. A first major study on the subject is a World Bank publication, including general chapters on trends in internationalisation, together with countries case studies (De Wit et al., 2005). Another supported European Commission Project, called Partnerships for Internationalisation of Higher Education, identified the main rationales and different approaches to internationalisation between Latin American and European institutions, as a tool for internationalisation strategic planning and quality assurance (PIHE NETWORK, 2006; De Wit, 2009). The OECD produced three reviews of TE systems: Mexico (OECD, 2008), Chile (OECD-The World Bank, 2009) and Santa Catarina State, Brazil (OECD, 2010a), including comments and recommendations on their respective internationalisation. The International Association of Universities (IAU) published three global surveys (2003, 2005 and 2010) on internationalisation with specific data and analysis on the region. Other relevant publications on the topic are on regional integration and TE globalisation (Zarur, 2008); the impact of the Bologna Process in LA (Malo, 2005; Brunner, 2009; Gacel-Ávila, 2010; García Guadilla, 2010; Fernández Lamarra, 2010); internationalisation, curricular design and reform (Beneitone et al., 2007; UEALC $6 \times 4,2008$ ); joint and double degrees in LA (Gacel-Ávila, 2009); 
academic mobility and brain drain (Zarur, 2008; García Guadilla, 2009; Marmolejo, 2009; Schwartzman, 2009); student mobility (Jaramillo and De Wit, 2009); foreign providers (Didou and Jokivirta, 2007); intra- and inter-regional networks for cooperation (Zarur, 2008). The topic is also mentioned in Gazzola and Didriksson (2008), Tünnermann (2008), López Segrera et al. (2009) and López Segrera and Rivarola (2010).

Nevertheless, a general shortage of systematic information on the topic, either from governments or institutions has to be highlighted, making a more precise analysis difficult, and is a first sign that such strategies are not based in a carefully planned process of decision making.

\section{Internationalisation in National and Regional Agendas}

According to the IAU 3rd Global Survey, the first external driver of internationalisation is worldwide government policies (31\%), followed closely by business and industry demand (30\%). In Europe, government policies rank first by a larger margin (38\%), North America being the exception to the trend $(16 \%)$, and consistent with a highly decentralised system. Participating Latin American TEIs report business and industry demand (31\%), and government policies 7 points behind $(24 \%)$, pointing out how weak governmental support is perceived, as collaboration between business and industry and the TE sector is traditionally low. In addition, TEIs declare receiving only $5 \%$ of their internationalisation funding from governmental sources, compared with the world average (WA) of $18 \%$ and the $32 \%$ for Europe (IAU, 2010).

This recent publication confirms the finding of the 2005 World Bank study, concluding that away from official discourse, internationalisation in reality is not a priority in the national agenda (De Wit et al., 2005). The case of Mexico is illustrative: although the 2007-2012 National Education Plan highlights the importance of foreign language learning, the development of international joint and double degrees, international programme accreditation, and supports the concept of a regional TE common area, no specific programmatic and follow-up strategies have been implemented towards this end. In a similar way, although Chile and Brazil have identified internationalisation as a priority in their national educational plans, TE reviews report the lack of specific programmes to make it a daily reality (OECD-The World Bank, 2009; OECD, 2010a). Furthermore, no regional strategy, at least significant, to attract foreign students and skilled scholars has been observed (De Wit et al., 2005), explaining the absence of available data in the different OECD and UNESCO reports.

To sum up, the scope of public policies, the insufficient number of programmes and levels of funding show that LA is a region where government 
support is one of the lowest in the world. It seems that the potential of comprehensive internationalisation is not yet fully assumed by policy makers, as a tool to support national programmes on quality and relevance, as international activities are mainly marginal to core institutional policies, mainly focusing on limited and individual student and faculty mobility. Furthermore, the lack of national leadership leaves the initiatives to institutions and individuals, but as the majority of institutions have to follow national guidelines for subsidies, thus the possible contribution of internationalisation to institutional development and the modernisation of the sector are greatly reduced.

\section{Institutional Strategies for Internationalisation}

\section{Importance of internationalisation in the institutional agenda}

$76 \%$ of the participating TEIs report that internationalisation has gained importance over the last 3 years, which is close to the world trend of $78 \%$. Nevertheless, this finding should be mitigated, as institutions further state that only $51 \%$ of institutional leaders attribute high importance to internationalisation, in contrast with the WA of $65 \%$ (IAU, 2010).

\section{Internationalisation - Main rationales, benefits, risks and obstacles}

The main rationales reported are to improve student preparedness for a globalised world (39\%); to internationalise curriculum and improve quality $(18 \%)$; and to strengthen research and knowledge capacity production $(16 \%)$. The substantial difference between the first rationale and the second and third ones emphasises students' needs to acquire an international profile, which is in tune with international trends, as this rationale ranks first for all regions, except that the percentage for our region is even higher (39\% against WA 30\%). This explains the increasing short-term student mobility (for one or two semesters), which is an emerging trend, as international mobility was traditionally dedicated to support postgraduate studies. In 2005, the IAU Global Survey reported as the first rationale for the region to strengthen research and knowledge (IAU, 2006), while in the World Bank Report, the main rationales were (1) institution building, (2) moving up to international standards and (3) quality enhancement (De Wit et al., 2005). The present trend is evidence of an evolving situation, as student-preparedness ranks first, while the other two have diminished in importance.

Noteworthy is the low ranking of enhancing international profile and reputation rationale $(6 \%)$, much lower than the WA of $15 \%$, and is further 
evidence of the absence of a strategy to promote TE sector overseas, and to attract international students or scholars. This could also be an implicit recognition that the quality of education has not yet achieved international standards.

The region perceived as the most significant benefits of internationalisation: increased international awareness of students $(30 \%)$, a higher percentage than the WA $(24 \%)$, which is congruent with the top rationale; strengthened research and knowledge production (18\%); enhanced international cooperation and solidarity (10\%); and increased international orientation of faculty/ staff. In 2005, the main benefit reported was by far: improved academic quality (De Wit et al., 2005).

As for key potential risks of increased internationalisation, TEIs report: Brain drain $(17 \%)$ - higher than the $10 \% \mathrm{WA}$ - pointing to a regional major problem related with academic mobility and the structure of national research systems; commodification and commercialisation of educational programmes $(12 \%)$; and increase of foreign degree mills and/or low quality providers $(12 \%)$, also higher than the WA $(9 \%)$. All these risks are illustrative of a regional reality, characterised by a low scientific development and an increasing presence of foreign providers, because of TE deficiencies in access, quality and relevance. Worth mentioning, in the 2005 IAU survey, the first reported risk was the loss of cultural identity in a global context, now ranking seventh (IAU, 2010), showing that the negative perception of internationalisation is losing ground.

The main internal barriers for internationalisation are: insufficient financial resources $(29 \%)$; limited expertise of staff and lack of foreign language proficiency $(12 \%)$; and too rigorous/inflexible curriculum $(9 \%)$. The main external barriers identified are: limited funding $(27 \%)$; difficulties for recognition of qualifications and programmes $(16 \%)$; and languages barrier (13\%) (IAU, 2010). All reported external and internal barriers show a higher percentage than the WA, and thus point to problems specific to the region. Even when institutions assert the increasing importance of internationalisation in their agenda over the last 3 years, $25 \%$ of them declare having no funding available for activities in contrast with $7 \%$ at WA, whereas $27 \%$ report having had an increase (below WA of $52 \%$ ), and another $15 \%$ to depend on external funding. These findings are contradictory: How can institutions state that internationalisation is a priority and have no budget for it? Even more if we take into account that LA is the region with the lowest level of public funding $(5 \%$ in contrast with WA of $18 \%$ and Europe of $32 \%$ ), and with less income from international students (5\%), in contrast with $13 \%$ in Asia-Pacific, $17 \%$ in North America and 15\% in Africa. All these indicators show LA as the region with less funding at all, both at national and institutional level (IAU, 2010). 
Constantly reported obstacles are: insufficient proficiency in foreign languages as a limitation to student and faculty mobility and cooperation projects, as well as the lack of curriculum flexibility, making difficult the curricular internationalisation and the establishment of international joint and double degrees (OECD-The World Bank, 2009). Similarly, OECD reviews in Brazil mention as main obstacles: government centralisation, limited efforts to internationalise the curriculum, absence of second language teaching, faculty members with insufficient global competencies and knowledge of international issues, purely symbolic institutional policies for internationalisation and limited resources (OECD, 2010a).

\section{Programmatic and organisational strategies for internationalisation}

Institutional internationalisation strategies are of two kinds: programmatic and organisational. $^{2}$ Programmatic strategies are aimed to integrate an international dimension in teaching, research, community outreach and cultural programmes, whereas organisational ones refer to the design and implementation of institutional policies, administrative frameworks and structures required for the viability of the process. The main characteristics of both strategies in LA are described in the following section.

\section{Organisational strategies}

Policy making and planning: In 2005, according to the World Bank Report, only very few institutions had implemented comprehensive internationalisation policies and strategic plans, meaning that international activities were not yet part of the core institutional development policies in teaching, curriculum and research, including planning, budgeting and quality assessment procedures. International activities were mainly reported to be individual initiatives; hence, lacking institutional direction. Nevertheless, the 2010 IAU survey shows some progress in this respect, as $79 \%$ of the TEIs report having included internationalisation in their mission statement or strategic plan, although significantly behind the WA of $87 \%$. Nevertheless, this is a misleading response, as only $57 \%$ of these same institutions mention later, having in fact, framed an institutional policy or a strategic plan for internationalisation, a percentage of 10 points below the WA of $67 \%$. For Brazil, the OECD reports that institutional missions only have an indirect mention of internationalisation, emphasising that internationalisation policies only exist in large institutions (OECD, 2010a).

These indicators show the same low level of commitment among national as institutional leaders, further evidence that internationalisation priority is more discourse than reality. 
Jocelyne Gacel-Ávila

The order of importance for international activities is reported to be (IAU, 2010):

1. outgoing mobility opportunities for students $(45 \%)$;

2. international research collaboration $(35 \%)$, lower than the world's average $(40 \%)$, showing a less proactive attitude in this respect, for reasons related to the relatively low level of research;

3. outgoing mobility opportunities for faculty and staff;

4. international student exchanges and attracting international students $(29 \%$ in contrast to $43 \% \mathrm{WA}$ ), consistent with lack of policy and low rate of inbound students.

Apart from confirming the increasing importance given to student mobility, the indicators show that no priority is made for innovative comprehensive strategies such as, for instance, the internationalisation of the curriculum, regional integration. This further confirms our hypothesis that the internationalisation approach of policy makers is traditional (mainly focused on mobility) and does not yet embrace the concept of comprehensive internationalisation, which is the world trend and is widely recommended to be implemented in other regions.

Quality assurance and accreditation: These procedures usually make only marginal mention of international activities, which are not explicitly included as a relevant indicator of academic development (Gacel-Ávila, 2007). As an example, the Mexican Inter-institutional Committee for Higher Education Evaluation mentions mobility of students and faculty, as well as foreign language teaching, as a recommendation but not as a requirement for accreditation or funding.

Administrative offices: Probably as a consequence of low priority in institutional agenda, international offices generally rank low in hierarchy, being on the fourth or fifth level and generally reporting to academic provosts, in contrast with the international trend where the hierarchical importance of international offices is increasing, assuming the rank of vice-presidency or provost for international affairs. This implies that international offices lack the necessary capacity to implement strategies and programmes of high complexity, and depend on senior officers who might not have the required international training and vision, and who can even see internationalisation activities overlapping with their area of competence. The international office is usually not included in the design and decision making on policies for research, teaching, curriculum and human resources. In addition, senior international officers, as well as staff are subject to a high turnover produced by the recurrent changes in institutional management, which is a trait of Latin 
American institutions. Therefore, the international team has a limited level of professionalisation and international expertise, thus provoking a lack of potential for the conception, design, implementation and promotion of internationalisation policies and strategies (De Wit et al., 2005).

\section{Programmatic strategies}

Student mobility programmes: Although it has been rising constantly in the last years, LA outbound student mobility is one of the lowest in the world with $6 \%$, after Africa (11\%) and just before Central Asia with 3.2\%, in contrast with $28.5 \%$ in East Asia-Pacific, $16.4 \%$ in North America and Western Europe, and $11 \%$ for Central and Eastern Europe (UNESCO Institute for Statistics, 2010).

In 2008, 64,768 Latin American students chose the United States as their favourite destination, with Mexico being the top sender (14,853 students), followed by 7,586 from Brazil and 6,669 from Colombia. The next favourite destination is Europe, with Spain as the leading country (18,406 students), France $(12,769)$, the United Kingdom $(7,809)$ and Germany $(7,356)$. Australia is receiving 2,741 LA students and is becoming an increasingly attractive destination. Most students are enroled in postgraduate programmes and receive scholarships from national programmes dedicated to the strengthening of scientific and research capacity. In contrast, the region hosts only $1.9 \%$ of the world's international students coming from the region itself (UNESCO Institute for Statistics, 2010). A striking fact reported in the IAU 3rd Global Survey is that LA appears to be of no priority for any other world region, including the region itself (IAU, 2010).

Intraregional mobility has notably increased in the recent years as a result of the establishment of university networks, like Red de Macro-universidades, UNIVERSIA, Grupo Montevideo, University Union of Latin America and the Caribbean (UDUAL), Inter-American Organization for Higher Education (IOHE), among others.

Faculty mobility programmes: For large public universities, international mobility among faculty has been a higher priority than student mobility, and is generally dedicated to an elite of full time academics holding postgraduate degrees. As over $60 \%$ of faculty are part-time and hold no postgraduate studies, the great majority does not benefit from these programmes, and are not able to participate in the internationalisation process. Most faculty members with an international profile are involved in projects partially funded by international organisations and institutions, their main partners being Germany, France, Spain, Great Britain, Italy, the United States and Canada. Intraregional faculty mobility and cooperation projects are traditionally limited. 
Jocelyne Gacel-Ávila

The internationalisation of the curriculum: The World Bank Report concludes that, in the last decade, '... very little curricular change has occurred in Latin America' (De Wit et al., 2005, 346). Similarly, the OECD reviews show that in Chile and Brazil, very few TEIs have integrated international contents in the curriculum and have policies to foster the development of intercultural and global competencies in students (OECD, 2010a). Only 27\% of the TEIs report strengthening international/intercultural content of the curriculum, giving this activity a lower importance than the WA and being internationalisation at home reported as the least frequent strategy (IAU, 2010). The main reported obstacle is the traditional undergraduate curricular model prevailing in the region, characterised by disciplinary overspecialisation, professional orientation, and a lack of flexibility making international collaboration and recognition difficult. The region has the least number of joint and double degrees of the world ( $29 \%$ compared with the WA of $44 \%)$, behind Africa with $54 \%$ and the Middle East with $48 \%$. Mentioned obstacles are: the lack of funding for student and faculty mobility; a limited internationalisation of the curriculum; the lack of institutional and national policies in this respect; and the low level of proficiency in foreign languages among students and professors. The main partner countries of joint and double degrees are France, Spain and Germany, followed by the United States; the large majority being established at undergraduate level by private institutions in the fields of business and management, followed by engineering. At postgraduate level, these programmes are predominantly in business and management, followed by social sciences. Public TEIs preferably organise them at doctoral level in social sciences and humanities. Traditional physical mobility is by far the favourite modality and is rarely combined with virtual means. Further evidence of insufficient proficiency of students and academics in foreign languages is that these programmes are generally taught in Spanish by foreign partners (Gacel-Ávila, 2009).

Teaching of foreign languages: As said, the insufficient proficiency in foreign languages among students, faculty and staff is constantly highlighted, and is the reason for the recommendation to integrate foreign language teaching in TE curriculum (OECD-The World Bank, 2009). Programmes taught in foreign languages are almost non-existent, and an obstacle to attracting international students. Fifty-three percent of TEIs report an increasing demand for foreign language learning and $49 \%$ report to have it as a requirement for graduation at postgraduate level, 15 points above the WA (34\%), with English being the language most in demand $(64 \%), 8$ points above the WA $(56 \%)$ (IAU, 2010).

Internationalisation of research is mainly developed in major public institutions, with France, Germany and Spain as the main partners, followed by the United 
Kingdom, the United States, Canada and Japan. International projects are predominantly carried out by an elite of internationally recognised scholars, and are usually co-funded by institutions and National Councils of Science and Technology existing in the different LA countries, through bi- and multi-lateral agreements with international sister organisations. Since the eighties, the trend has been to move away from cooperation for development owing to the advancement of science, and the increasing number of qualified researchers. Researchers actively participate in international networks, but rather on an individual basis than in response to institutional planned strategy and incentives. Cooperation with countries in the northern hemisphere is privileged; nevertheless intraregional cooperation is definitely on the rise. The Latin American and Caribbean Area for Higher Education (ENLACES) provides good evidence of this, and has among its main objectives fostering intraregional cooperation, acting as a platform for regional networks (to act as a network of networks), in order to develop a comprehensive framework for research at regional level (ENLACES, 2009).

Regional integration: Due to an influence from the Bologna Process, debate is taking place in the region on intraregional academic integration, and participation in the Latin American and Caribbean-European Union Common Area of Higher Education, as well as in the Ibero-American Space for Knowledge promoted by UNIVERSIA. By the same token, other ENLACES objectives have to be mentioned: fostering the creation of a Latin American and the Caribbean Common Area for Higher Education; supporting a process of regional convergence; and working out a framework for the implementation of a new educational model, by drawing on lessons learnt from the Tuning Latin-America and $6 \times 4$ projects, which are based on the development of competencies in students (ENLACES, 2009). The feasibility of a process like Bologna in LA has given rise to debate and criticism (Brunner, 2009; GacelÁvila, 2010), leading to the conclusion that the model presents great limitation in the case of LA. Nevertheless, this debate has opened an avenue for further research on a convergence process and educational models suitable for the region, which is in itself promising.

\section{Conclusions}

From the analysis of the findings mentioned, the region has made undeniable progress in its internationalisation process. Nowadays, the topic is largely acknowledged as key for the improvement of TE quality and relevance, and is highly valued for student preparedness, the advancement of knowledge production, and national and regional competitiveness. This trend is evidenced 
by an increase in international student and academic mobility and important participation in research international networks. The large majority of TEIs have integrated internationalisation into their strategic plans and are multiplying efforts to raise their international activities. Nevertheless, the process is limited due to the attention required by other pressing areas, as well as the lack of long-term public education policies and scarce financial resources. Government policies and programmes in internationalisation lack coordination, direction and long-term perspective, as well as human and financial resources. Declarations made by education authorities on the importance of internationalisation are mainly rhetorical, and rarely yield strategies of change in institutional development. This situation is evidenced by inadequate and inefficient organisational structures, short-term programmes and the lowest world levels of funding, either national or institutional. As a result, notwithstanding the progress made, the rates of outgoing students are among the lowest in the world, the internationalisation of curricula is almost inexistent, LA has the lowest number of joint and double degrees, there are no regional strategies to attract international students and talented scholars, insufficient proficiency in foreign languages and cultures is a trait of LA students, scholars with international profiles are the exception and so on. In other words, efforts need to be multiplied towards institutionalisation of the international dimension and the implementation of a comprehensive internationalisation concept. To this end, internationalisation strategies must be integrated into the mainstream of institutional development, and policy makers must consider it as a means and cost-effective strategy to go at a faster pace in TE development, and not as a marginal and costly activity. International cooperation has to be used according to well-planned institutional strategies to overcome existing deficiencies in relevant areas. The international dimension must be systematically integrated into all development policies in teaching, curricular design, research, innovation, human resources and outreach services. In addition, the belief in overcoming present deficiencies without making use of internationalisation will, in the end, widen the gap, as other regions of the world are now considering internationalisation as part of their daily strategies and institutional culture. In other words, LA internationalisation strategies are mainly focused on strategies affecting individuals (mobility), and therefore have no lasting impact on the system, which largely limits the contribution of internationalisation to quality improvement, TE reform and transformation. In this regard, the limited scope of internationalisation strategies could be due to a lack of conceptualisation on the part of educational policy makers (Van der Wende, 1997). Indeed, the conceptualisation of comprehensive internationalisation is still unfamiliar and unknown by the majority of policy and decision makers. Basic theories and concepts of internationalisation are not very popular topics for researchers on TE in LA either, thus making these 
concepts fragile and unknown. Furthermore, the various social and university stakeholders do not share a common understanding of these basic concepts, and there is no consensus with respect to the importance, significance, definition, scope and strategy of internationalisation. For this reason, more research is needed in this field in the region, as it is crucial to create a thorough understanding of internationalisation benefits and potential for the reform and advancement of TE in LA.

As a conclusion, education must be at the forefront of the Latin American agenda for development including internationalisation as a key strategy for the sector advancement, such as in the case of other countries. Although recent TE reforms are broadly consistent with international trends, the region might not be moving at a fast enough pace, as high-income and other emergent nations are rapidly advancing. Therefore, LA should progress even faster in order to close the gap, as the Knowledge Society could make the differences even more pronounced. Creative and innovative approaches are needed to meet this challenge, and internationalisation should be considered as an effective means of moving in this direction at a faster pace.

\section{Notes}

1 Coombs Report, the OECD Mexico's review of TE and the Inter-American Development Bank report on Higher Education in Latin America and the Caribbean.

2 This distinction is part of the framework for planning and quality assessment developed for the International Quality Review Programme (IQRP) by the IMHE of the OECD.

\section{References}

Beneitone, P., González, J. and Wagenaar, R. (eds.) (2007) Reflexiones y perspectivas de la educación superior en América Latina, España: Universidad de Deusto.

Brunner, J.J. (2009) 'The Bologna Process from a Latin American perspective', Journal of Studies in International Education 13(4): 417-438.

Comisión Económica para América Latina y el Caribe (CEPAL). (2010) Panorama social de América Latina 2010, Santiago de Chile: CEPAL.

De Wit, H. (ed.) (2009) 'Benchmarking the Internationalisation Strategies of European and Latin American Institutions of Higher Education', in Measuring Success in the Internationalisation of Higher Education, Amsterdam: EAOE, pp. 125-135.

De Wit, H., Jaramillo, C., Gacel-Ávila, J. and Knight, J. (eds.) (2005) Higher Education in Latin America: The International Dimension, Washington DC: The World Bank.

Didou, S. and Jokivirta, L. (2007) 'Foreign education activity in Latin America and the Caribbean', Observatory on Borderless Higher Education.

ENLACES. (2009) 'Declaración de Lima', http://www.iesalc.unesco.org.ve/index.php?option= com_content\&view=article\&id=1186\&Itemid=560\&lang=es, accessed 12 December 2010.

Fernández Lamarra, N. (2010) 'La convergencia de la educación superior en América Latina y su articulación con los Espacios Europeo e Iberoamericano. Posibilidades y límites', Revista de Avaliação da Educação Superior, http://submission.scielo.br/index.php/aval/article/view/32845/ 3148, accessed 10 November 2010. 
Fullan, M. (2006) Change Theory: A Force for School Improvement, Victoria: Centre for Strategic Education.

Gacel-Ávila, J. (2007) 'The process of internationalization of Latin American higher education', Journal of Studies in International Education 11(3/4): 400-409.

Gacel-Ávila, J. (2009) 'Joint and double degree programmes in Latin America: Patterns and trends', The Observatory on Borderless Higher Education.

Gacel-Ávila, J. (2010) 'Factibilidad del Proceso de Bolonia en América Latina', in F. López Segrera and D. Rivarola (eds.) La Universidad ante los desafios del siglo XXI, Asunción: Centro Paraguayo de Estudios Sociológicos.

García Guadilla, C. (2009) La emigración del personal calificado desde paises de América Latina y el Caribe. Perspectiva IESALC-UNESCO. Organización Internacional para las Migraciones, Caracas: Sistema Económico Latinoamericano y del Caribe.

García Guadilla, C. (2010) 'El espacio ENLACES en el contexto de las nuevas dinámicas de internacionalización universitaria', in J. Cadena (ed.) La universidad latinoamericana a discusión, Caracas: IESALC-UNESCO.

Gazzola, A. and Didriksson, A. (eds.) (2008) Trends in Higher Education in Latin America and the Caribbean, Caracas: IESALC-UNESCO.

Gómez Buendía, H. (1998) 'Educación: La agenda del siglo XXI. Hacia un desarrollo humano', Universidad Nacional de Colombia, http://www.ing.unal.edu.co/admfac/iei/comunicados/docs/ educacion_agenda_siglo_XXI.pdf, accessed 15 July 2011.

International Associations of Universities. (2006) Internationalization of Higher Education: New Directions, New Challenges, 2005 IAU Global Survey Report, Paris: IAU.

International Associations of Universities. (2010) in E. Egron-Polak and R. Hudson (eds.) Internationalisation of Higher Education: Global Trends, Regional Perspectives. IAU 3rd Global Survey, Paris: IAU.

Jaramillo, I. and De Wit, H. (2009) 'Student mobility trends in Latin America', IIE Networker, http://www.nxtbook.com/nxtbooks/naylor/IIEB0209/\#/16, accessed 17 November 2010.

Knight, J. and De Wit, H. (1995) 'Strategies for Internationalisation of Higher Education, Historical and Conceptual Perspectives', in H. De Wit (ed.) Strategies for Internationalisation of Higher Education, Amsterdam: EAIE, pp. 5-32.

Knight, J. and De Wit, H. (eds.) (1999) Quality and Internationalisation in Higher Education, Paris: OECD.

López Segrera, F., Brock, C. and Días Sobrinho, J. (eds.) (2009) Higher Education in Latin America and the Caribbean 2008, Caracas: IESALC-UNESCO.

López Segrera, F. and Rivarola, D. (eds.) (2010) La Universidad ante los desafios del siglo XXI, Asunción: Centro Paraguayo de Estudios Sociológicos.

Malo, S. (2005) 'El Proceso de Bolonia y la educación superior en América Latina', Foreign Affairs en Español 5(2): 12-13.

Marmolejo, F. (2009) 'Redes, movilidad académica y fuga de talentos en América del Norte: el caso de los académicos mexicanos', in S. Didou and E. Gérard (eds.) Fuga de cerebros, movilidad académica, redes cientificas. Perspectivas latinoamericanas, México: IESALC-CINVESTAV, pp. 101-116.

Mestenhauser, J. (1998) 'Internationalization of higher education: A cognitive response to the challenges of the twenty-first century', International Education Forum 18(1 and 2): 3-7.

OECD. (2008) OECD Reviews of Tertiary Education Mexico, Paris: OECD.

OECD. (2010a) Reviews of National Policies for Education: Santa Catarina State, Brazil, Paris: OECD.

OECD. (2010b) PISA 2009 Results: What Students Know and Can Do, Paris: OECD.

OECD-The World Bank. (2009) Tertiary Education in Chile, Paris: OECD. 
.ن. Jocelyne Gacel-Ávila

柋: Comprehensive Internationalisation in Latin America

510

PIHE Network. (2006) Prácticas y tendencias para la internacionalización y la cooperación entre universidades de América Latina y Unión Europea, Alicante: PIHE Network.

Schwartzman, S. (2009) 'Nacionalismo versus Internacionalismo en las políticas de formación de recursos humanos de alto nivel', in S. Didou and M. Gérard (eds.) Fuga de cerebros, movilidad académica, redes científicas. Perspectivas Latinoamericanas, México: IESALC-CINVESTAV, pp. 63-74.

Tünnermann, C. (ed.) (2008) La educación superior en América Latina y el Caribe: A diez años después de la Conferencia Mundial de 1998, Colombia: UNESCO-IESALC.

UEALC $6 \times 4$. (2008) 'Propuestas y acciones universitarias para la transformación de la educación superior en América Latina. Informe Final del Proyecto $6 \times 4$,', Asociación colombiana de Universidades, http://www.6x4uealc.org/site2008/p01/01.pdf, accessed 25 November 2010.

UNESCO Institute for Statistics. (2010) Global Education Digest 2010, Montreal: UNESCO.

Van der Wende, M. (1997) 'Missing Links: The Relationship between National Policies for Internationalisation and those for Higher Education in General', in T. Kälvermark and M. Van der Wende (eds.) National Policies for the Internationalisation of Higher Education in Europe, Estocolm: National Agency for Higher Education.

Zarur, X. (2008) 'Regional Integration and Internationalization of Higher Education in Latin America and the Caribbean', in A. Gazzola and A. Didriksson (eds.) Trends in Higher Education in Latin America and the Caribbean, Caracas: IESALC-UNESCO, pp. 175-231. 